\title{
Estrada da Vida (1952) e a Cinematográfica Terras do Brasil: A presença das mulheres no cinema brasileiro do início dos anos 1950
}

\author{
Livia Perez \\ Universidade de São Paulo \\ lperezde@ucsc.edu \\ https://orcid.org/0000-0002-2608-6987
}

RESUMO O artigo reúne informações sobre a iniciativa de Tânia Simões e Jovita de Almeida à frente da Cinematográfica Terras do Brasil, produtora fundada no começo dos anos 1950 em São Paulo, que resultou na filmagem de um único longa-metragem, Estrada da Vida (1952), classificado como inacabado no catálogo da Cinemateca Brasileira. A partir de publicações na imprensa e do roteiro original do filme, o texto propõe uma reflexão sobre a abordagem exotificada e desconfiada acerca da presença das mulheres no cinema brasileiro e lança questões sobre o processo de feitura do filme e o destino de suas autoras.

Palavras-Chave Cinematográfica Terras do Brasil; Estrada da Vida (1952); Tânia Simões; Jovita de Almeida; mulheres cineastas.

\section{Diretoras de cinema e a tentativa industrial de São Paulo na década de 1950}

Entre 1949 e 1953, São Paulo viveu um período "rico em filmes e acontecimentos" (Salles Gomes 1996, 78), marcado pela efervescência cultural da cidade com a fundação de instituições como o Museu de Artes de São Paulo - MASP (1948), Museu de Arte Moderna - MAM (1947), e o Teatro Brasileiro de Comédia - TBC (1948) patrocinadas e incentivadas pela burguesia paulista (Galvão 1981; Catani 2018). A difusão cultural na área cinematográfica ocorreu através da criação de empresas como Vera Cruz (1949), Maristela (1950) e Multifilmes (1952), com inspiração nos estúdios grandes hollywoodianos e manutenção de elenco fixo, tal como o star system, além da contratação de técnicos estrangeiros. $\mathrm{Na}$ esteira destas grandes companhias e em 
meio à empolgação pela "cota de tela", que instituiu, a partir de dezembro de 1945, a obrigatoriedade de exibição de um longametragem brasileiro para cada três estrangeiros (Simis 2010), foram criadas duas dezenas de produtoras em São Paulo, além da ocorrência de realizadores de trajetória independente, sobretudo após 1955, beneficiadas pelos financiamentos do Banco do Estado de São Paulo (Catani 2018) e (Costa e Canepa 2018). ${ }^{1}$

Durante esta tentativa de industrialização do cinema paulista (Autran 2013), não há registros sobre a existência de filmes dirigidos por mulheres, exceto Estrada da Vida (1952), de Tânia Simões. Mencionado por Galvão (197-) e Pizoquero (2006), o filme não faz parte das publicações que se dedicaram a mapear e visibilizar o cinema dirigido por mulheres na história do cinema brasileiro (Munerato e Oliveira 1982; Hollanda 1989), talvez pela pecha de inacabado, como consta na base de dados da Cinemateca Brasileira. Os únicos registros de longasmetragens dirigidos por mulheres em São Paulo, nos anos 1950, datam do fim da década (Hollanda 1989), quando as italianas Maria Basaglia ${ }^{2}$ e Carla Civelli, ${ }^{3}$ com experiências prévias na Itália, ${ }^{4}$ dirigiram seus filmes no Brasil. Basaglia realizou Macumba na Alta (1958) e O Pão que o Diabo Amassou (1959), e Civelli dirigiu (roterizou, montou e produziu) Um Caso de Polícia! (1959). De acordo com o levantamento de Pereira Jr (1979), Civelli ainda teria dirigido Helena (1959) e Homem Fora do seu Meio (1959), enquanto Basaglia teria dirigido o título Brasil Acontece (1963), filmes que constam como inacabados na base de dados da Cinemateca Brasileira.

Do mesmo modo, não há nenhuma linha publicada pelos críticos mais reconhecidos do período sobre Simões e seu único filme, Estrada da

\footnotetext{
${ }^{1}$ Estes autores se dedicaram à pesquisa das obras e trajetórias dos cineastas independentes Roberto Santos, Alberto Pieralisi, Rodolfo Nanni, Galileu Garcia, Agostinho Martins Pereira, Oswaldo Sampaio que, sem um esquema de produção empresarial, realizavam filmes com recursos limitados (Catani 2018) e cujas inciativas cinematográficas resultaram nos ciclos de cinema como o ciclo do cangaço, séries televisivas em $35 \mathrm{~mm}$ e o ciclo do cinema paulista erótico (Costa e Canepa 2018).

${ }^{2}$ Basaglia e seu marido Marcello Albani eram apoiadores do movimento facista cinema di salò, em referência à República de Salò ou República Social Italiana instaurada em 23 de setembro de 1943 na parte do território italiano não ocupado pelos Aliados (Poppi 2002, 43-102). É provável que tenham vindo ao Brasil fugindo de represálias pelo apoio ao regime fascista.

${ }^{3}$ Civelli imigrou a convite de seu irmão, o produtor Mário Civelli, fundador da Multifilmes (Andrade 1997).

${ }^{4}$ De acordo com Poppi (2002, 43), Basaglia havia dirigido Sua Altezza ha detto: no! (1953-1954) e Sangue di zingara (1955-1956), enquanto Andrade (1997, 2) afirma que apesar de Civelli "ter trabalhado como montadora de filmes italianos durante a década de 1930, consulta feita à Cinemateca de Roma mostrou que seu nome não constava nos registros."
} 
Vida (1952). O filme inacabado pode não ter sido notado pela crítica, apesar de Simões ter participado com a Cinematográfica Terras do Brasil, produtora da qual era sócia, do I Congresso Paulista de Cinema Brasileiro, onde muitos destes críticos estiveram presentes e atuantes. A maior atenção dedicada à Cinematográfica Terras do Brasil e Estrada da Vida (1952) apareceu em duas dezenas de notas e reportagens publicadas na imprensa tradicional ou especializada, como Diário da Noite (RJ), Correio Paulistano (RJ), A Noite (RJ), A Cena Muda (RJ), e também em veículos mais sensacionalistas como a Revista da Semana (RJ) e O Malho (RJ).

Apesar da pendente confirmação de material fílmico remanescente na Cinemateca Brasileira, fechada desde agosto de 2020 e alvo de desmonte do governo de Jair Bolsonaro desde 2018, a pesquisa se baseia em fontes primárias disponíveis na Hemeroteca da Biblioteca Nacional e no roteiro original de Estrada da Vida (1952), localizado na Sociedade Brasileira de Autores Teatrais (SBAT), para lançar questionamentos sobre a presença misteriosa, no panorama cinematográfico da época, de Tânia Simões e da Cinematográfica Terras do Brasil, que fundou e administrou ao lado de Jovita de Almeida.

Diante da ausência de filmes dirigidos por mulheres durante a tentativa industrial do cinema paulista, não seria válida a investigação de Estrada da Vida (1952) com a intenção de refletir sobre as condições que permearam esse contexto? Quem foi Tânia Simões, a mulher que ousou realizar um filme durante a tentativa industrial de São Paulo? Quais características de Estrada da Vida (1952) e de sua produção podemos saber a partir da divulgação da imprensa? A trajetória de Simões, figura anônima, poderia integrar a lista de diretoras na década de 1950, ressaltando a continuidade da presença das mulheres no cinema brasileiro?

A seguir apresento um panorama detalhado e ilustrado sobre a cobertura da imprensa às filmagens de Estrada da vida (1952), à Cinematográfica Terras do Brasil, a Simões e sua sócia Jovita de Almeida, com almejo de traçar um histórico amplo, até agora desconhecido, e instigar uma reflexão sobre a iniciativa empreendedora da produtora e o contexto de produção do seu único longa-metragem. Reconstruindo a trama a partir da apresentação do roteiro, espera-se contribuir com os estudos sobre a presença das mulheres na história do cinema brasileiro e, diante das lacunas e limitações da cobertura jornalística, enfatizar perguntas e 
questionamentos com o propósito de levantar questões para continuidade desta pesquisa.

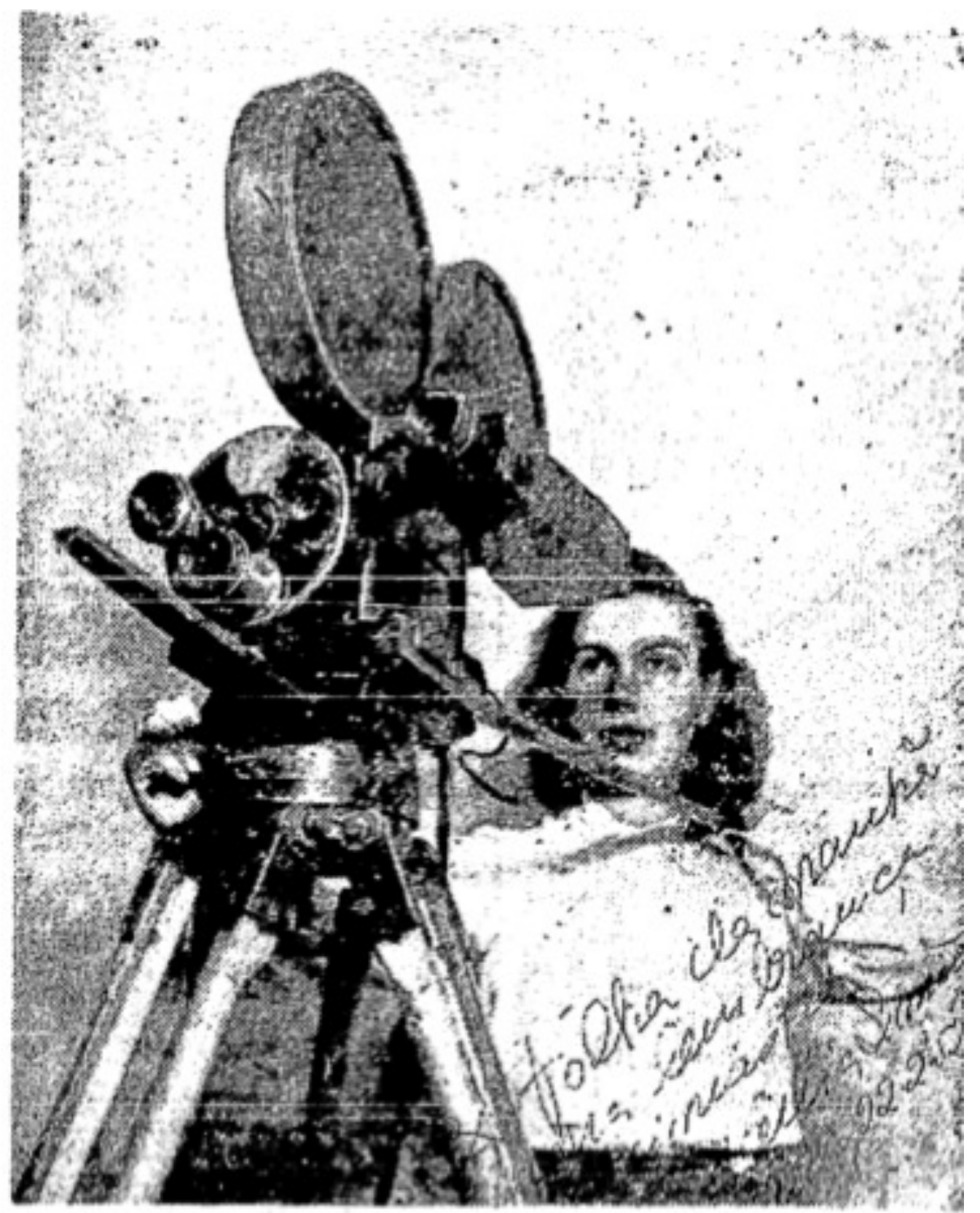
"ESTRADA DA VIDA" - Tania Simós, a cinegrafista de "Es-
trada da Vida", filme que brevemente serd lançado na Cinelandia

Imagem 1: Tânia Simões em foto divulgada na Folha de São Paulo, 1 de março de 1952. | @ Hemeroteca Digital Brasileira/ Biblioteca Nacional. 


\section{Terras do Brasil, uma cinematográfica de mulheres}

Tânia Simões, nome artístico de Dirza Simões Diniz (n. Rio de Janeiro, 1921), iniciou sua carreira artística na dança, utilizando o pseudônimo de Tania Tanagra, com o qual fundou e liderou o Ballet Tania Tanagra, companhia especializada em números afro-brasileiros e indígenas, formada por seis girls e ela própria como solista. O grupo viajou pelo Brasil se apresentando nos palcos de teatros, cineteatros e casinos, e alcançou grande prestígio na segunda metade da década de 1940, quando se apresentou em Buenos Aires. ${ }^{5} \mathrm{Na}$ virada da década de 1950, Tanagra abandonou os palcos e trocou o sobrenome para Simões. Neste período, afirmou ter estudado fotografia e adquirido uma pequena câmara de 16 milímetros com a qual filmava cinejornais, que depois substituiu por uma de 35 milímetros, pois "precisava fazer algo maior, algo que empolgasse o país, que realizasse seus desejos: um filme de longa-metragem."

Em maio de 1951, o Jornal de Notícias publicou que Simões era a "primeira cinegrafista do mundo" a documentar os últimos dias do médico Napoleão Laureano, vítima de câncer. ${ }^{7} \mathrm{Na}$ reportagem, Simões discorre sobre a decupagem, os ângulos e o enquadramentos das tomadas. Identificando-se como uma das diretoras da Terras do Brasil, Simões declara também que a companhia havia sido formada há pouco mais de um ano, ou seja, em 1950, após uma reunião com outras mulheres, e classificou o feito como "inédito". Era também membra da produtora Jovita de Almeida Draeger (n. Erechim, 1928), ${ }^{8}$ vencedora de um concurso de candidatos ao cinema nacional promovido pela revista $A$ Cena Muda, em parceria com a América Filmes, ${ }^{9}$ ocasião em

\footnotetext{
${ }^{5}$ A Noite, 4 de Junho de 1945, p. 7. Disponível em http://memoria.bn.br/DocReader/DocReader.aspx?bib=348970_04\&pesq=\%22Tania\%20Tanagra\%22\&pas $\underline{\mathrm{ta}=\text { ano\%20194\&pagfis }=34026}$

${ }^{6}$ Domingos de Lucca JR., 1952. "Mulheres descobrem a $7{ }^{a}$ Arte". Revista da Semana, 22 de março, 1952, pp. 4 e 18. Disponível em:

http://memoria.bn.br/DocReader/DocReader.aspx?bib=025909 05\&pesq=\%22T\%C3\%A2nia\%20Sim\%C3 \%B5es\%22\&pasta $=$ ano\%20195\&pagfis $=3837$

7 "Filmado pela primeira cinegrafista do mundo o drama do doutor Laureano", Jornal de Notícias, 12 de maio de 1951, p. 12. Disponível em:

http://memoria.bn.br/DocReader/DocReader.aspx?bib=583138\&pesq=\%22T\%C3\%A2nia\%20Sim\%C3\%B5 es\%22\&pasta=ano\%20195\&pagfis $=17277$

${ }^{8}$ De acordo com registro no livro A15, fl 49, termo 339. Cartório da $1^{\text {a }}$ Zona de Erechim-RS.

${ }^{9}$ A Cena Muda, 5 de julho de 1951, p. 38. Disponível em:

http://memoria.bn.br/DocReader/DocReader.aspx?bib=084859\&pesq=\%22Jovita\%20de\%20Almeida\%22\& pasta $=$ ano $\% 20195 \&$ pagfis $=54878$
}

aniki A Pesquisa Histórica no Cinema Ibero-americano | Historical Research in Ibero-American Cinema 
que declarou nas páginas da publicação seu desejo de "ser artista de cinema, de preferência em papéis de cínica e mulher má” ${ }^{10}$

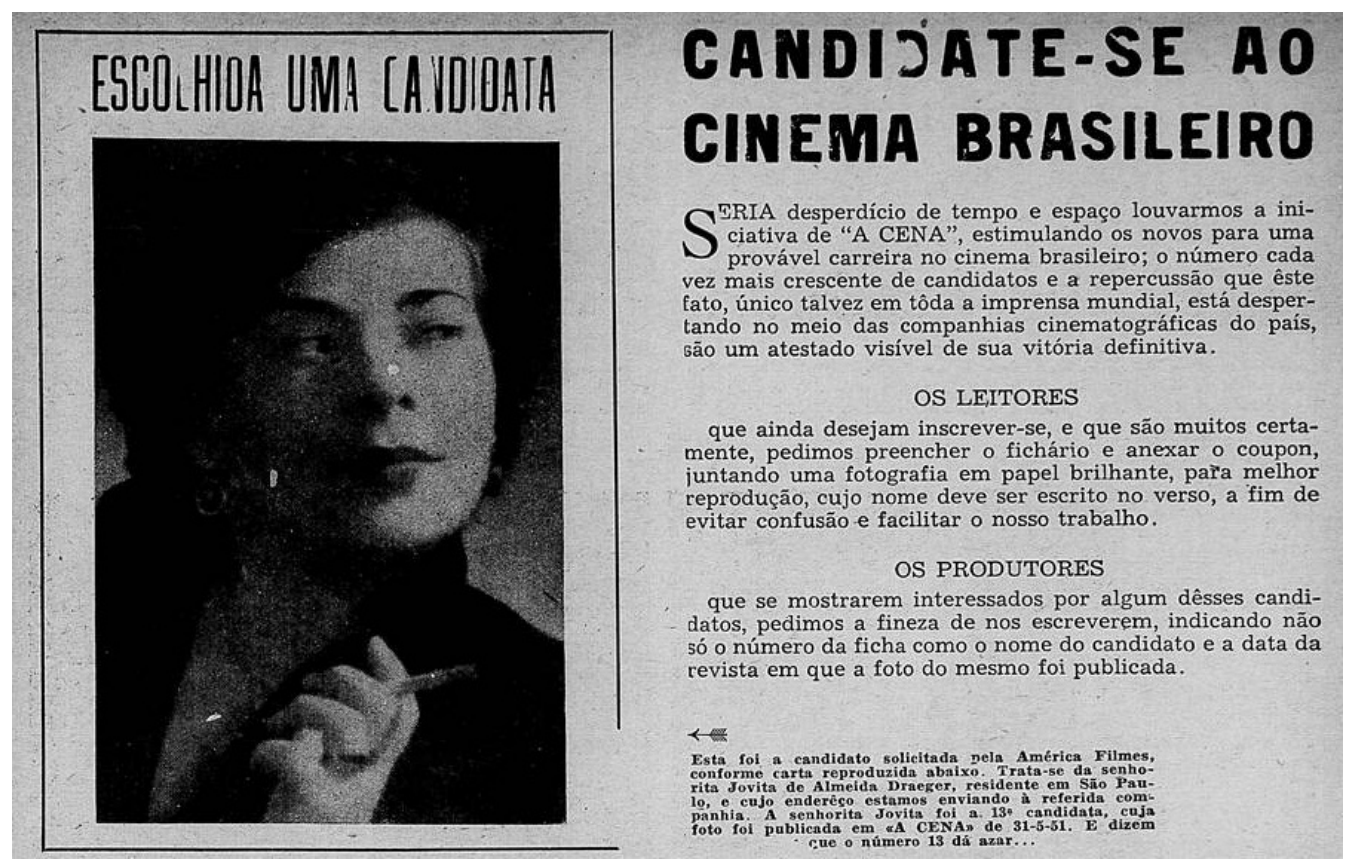

Imagem 2: Jovita de Almeida anunciada como ganhadora do concurso, A Cena Muda, 5 de julho de 1951. | ๑ Hemeroteca Digital Brasileira/ Biblioteca Nacional.

Em meados de 1951, a Cinematográfica Terras do Brasil e o Estúdio Índios do Brasil, localizados na rua Sergipe, 96 - sala 33, em São Paulo, estavam em pleno funcionamento com técnicos e material do mais moderno. De acordo com nota publicada na imprensa, estavam também prontos para satisfazer plenamente "o público mais exigente no que concerne a filmes de boa qualidade", tendo a seus serviços uma moça operando como cinegrafista. ${ }^{11}$ Nos registros do Diário Oficial do Estado de São Paulo ${ }^{12}$ consta que em 23 de julho de 1952, cerca de um ano

10 A Cena Muda, 31 de maio de 1951, p. 14 . Disponível em: http://memoria.bn.br/DocReader/DocReader.aspx?bib=084859\&pesq=\%22Jovita\%20de\%20Almeida\%20D $\underline{\text { raeger } \% 22 \& \text { pasta }=\text { ano } \% 20195 \& \text { pagfis }=54688}$

11 "Tomadas e Panoramas", Fon Fon, 16 de junho de 1951, p. 21. Disponível em http://memoria.bn.br/DocReader/DocReader.aspx?bib=259063\&pesq=\%22Cinematogr\%C3\%A1fica\%20T erra\%20do\%20Brasil\%22\&pasta=ano\%20195\&hf=memoria.bn.br\&pagfis $=134254$

${ }^{12}$ Diário Oficial do Estado de São Paulo. Imprensa Oficial, no 164, Ano 62º, 23 de julho de 1952, p. 7, Disponível 
depois da publicação citada, o capital social da empresa foi elevado de 22 mil cruzeiros para 100 mil cruzeiros, dividido em partes iguais entre as sócias Dirza Simões Diniz e Jovita de Almeida Draeger. Podemos ter dimensão do porte da microempresa a partir do capital social da Vera Cruz, que, em 1951, passou de 7,5 milhões a 25 milhões de cruzeiros (Catani 2018).

$\mathrm{Na}$ imprensa, Simões e Almeida se denominavam orgulhosamente como "uma equipe única de duas mulheres", parte "de uma companhia cinematográfica que elas idealizaram e fundaram, realizando, em pouco tempo seu primeiro filme e já prometendo um segundo que conforme dizem (diziam) 'abafará' o Brasil”. Se, por um lado, o fato de serem responsáveis pela "filmagem, revelação, montagem, direção, argumentação, técnica de luz e de som, decupagem, dublagem, etc". ${ }^{13}$ empolgava a imprensa de caráter mais sensacionalista, por outro, o acúmulo de funções comprova como era modesto o empreendimento.

$\mathrm{Na}$ primeira entrevista à imprensa como representante da Terras do Brasil em maio de $1951,{ }^{14}$ Simões mencionou planos de organizar um "Sindicato dos Produtores Cinematográficos do Brasil" para proteção dos filmes, companhias e produtores nacionais, declarando que haviam telegrafado ao presidente da República solicitando permissão para que Alberto Cavalcanti fosse seu dirigente sindical. Essa declaração indica que Simões tinha consciência dos acontecimentos políticos que movimentavam a classe cinematográfica naquele momento, o que é corroborado pela adesão da Cinematográfica Terras do Brasil, entre um total de vinte e sete companhias participantes, ao I Congresso Paulista de Cinema Brasileiro (CPCB). ${ }^{15}$

https://www.imprensaoficial.com.br/DO/BuscaDO2001Documento 11 4.aspx?link=\%2f1952\%2fexecutiv o\%2fjulho\%2f23\%2fpag_0007_746FMAV441SH9e17TA3H4TATC59.pdf\&pagina=7\&data=23/07/1952\&ca $\underline{\text { derno }=\text { Executivo\&paginaordenacao }=100007}$

${ }^{13}$ Domingos de Lucca JR., "Mulheres descobrem a $7^{a}$ Arte".

14 "Filmado pela primeira cinegrafista do mundo o drama do doutor Laureano", Jornal de Notícias, 12 de maio de 1951, p. $04 . \quad$ Disponível em: http://memoria.bn.br/DocReader/DocReader.aspx?bib=583138\&pesq=\%22T\%C3\%A2nia\%20Sim\%C3\%B5 es\%22\&pasta $=$ ano $\% 20195 \&$ pagfis $=17269$

${ }^{15}$ Sobre o Congresso, veja-se "Organizações de Cinema em São Paulo", A Noite, 29 de março de 1952, pp. 5 e 27. Disponível em:

http://memoria.bn.br/DocReader/DocReader.aspx?bib=348970 05\&pesq=\%22T\%C3\%A2nia\%20Sim\%C3 \%B5es\%22\&pasta=ano\%20195\&pagfis=11814; e "Lista de participantes convocando para participação no I Congresso Paulista de Cinema Nacional”, Cine Repórter: Semanário Cinematográfico, 1 de março de 1952, p. 3. Disponível em:

http://memoria.bn.br/DocReader/DocReader.aspx?bib=085995\&pesq=\%22T\%C3\%A2nia\%20Sim\%C3\%B5 es\%22\&pasta $=$ ano $\% 20195 \&$ pagfis $=2194$ 
Entre 1950 e 1952, a notícia de uma produtora formada apenas por mulheres circulou em artigos e reportagens que ora celebravam a existência de Simões, Almeida e sua produtora com exotismo e surpresa por seu pretenso pioneirismo, ora questionavam suas capacidades como diretoras, produtoras e empresárias. Destacando a originalidade da produtora ser administrada totalmente por mulheres que "idealizam, esquematizam, escrevem, ensaiam, dirigem, filmam e revelam”, o Diário da Noite ressaltou que na empresa não havia "lugar para homem a não ser para desempenhar o papel de galã". ${ }^{16}$ Por sua vez, O Malho reconheceu Simões como "cérebro da produtora” e única no mundo a desempenhar "simultaneamente as funções de diretora geral, decupagem, revelação, roteiros etc." ${ }^{17}$ A Noite destacou com perplexidade que até os cinegrafistas eram "do sexo feminino, distribuindo-se, daí, outras mulheres para os demais postos de direção". ${ }^{18}$ A reportagem menciona curtas metragens da companhia, sem, no entanto, citar títulos e revela que a diretora trabalhara previamente como cinegrafista de cinejornais. Igualmente, a Revista da Semana destacou os shorts e a equipe exclusivamente feminina, ironizando a ausência do "sexo forte" e o fato dos homens não terem sido convidados, afirmando que "Tânia pode ser, assim, a primeira cineasta do Brasil a realizar uma obra de envergadura, capaz de influir no panorama cinematográfico brasileiro". ${ }^{19}$

Em longa reportagem assinada, o jornalista Lucca JR. da Revista da Semana afirma ter visitado os sets de filmagem de Estrada da Vida, relatando sua surpresa ao "topar com aquela simpática loira mignon manejando uma gigantesca filmadora de 35 milímetros, ao som dos berros de outra jovem." ${ }^{20}$ Em matéria de abordagem misógina, que

\footnotetext{
16 "Cinema da Mulher para os Dois Sexos", Diário da Noite, 17 de setembro de 1951, p. 6. Disponível em: http://memoria.bn.br/DocReader/DocReader.aspx?bib=093351\&pesq=\%22T\%C3\%A2nia\%20Sim\%C3\%B5 es\%22\&pasta $=$ ano\%20195\&pagfis $=22040$

17 “Cinematográfica Terra do Brasil”, O Malho, Abril de 1952, Ano L, p. 27. Disponível em:

http://memoria.bn.br/DocReader/DocReader.aspx?bib=116300\&pesq=\%22T\%C3\%A2nia\%20Sim\%C3\%B5 es\%22\&pasta $=$ ano $\% 20195$ \&pagfis $=102436$

18 "O Belo Sexo invade o cinema", A Noite, 27 de março de 1952, p. 5. Disponível em:

http://memoria.bn.br/DocReader/DocReader.aspx?bib=348970_05\&pesq=\%22T\%C3\%A2nia\%20Sim\%C3 \%B5es\%22\&pasta $=$ ano\%20195\&pagfis $=11782$

19 "Só para Mulheres". Revista da Semana 26 de janeiro de 1952, p.56. Disponível em: http://memoria.bn.br/DocReader/DocReader.aspx?bib=025909 05\&pesq=\%22T\%C3\%A2nia\%20Sim\%C3 \%B5es\%22\&pasta $=$ ano $\% 20195 \&$ pagfis $=3411$

${ }^{20}$ Domingos de Lucca JR., "Mulheres descobrem a 7a Arte".
} 
indagava o que os homens pensariam de tal iniciativa, ele designou a dupla como mulheres destemidas que não queriam saber de saias. Almeida foi descrita com uma "energia masculina", alguém que falava pouco e trabalhava muito, segundo ele "coisa rara em mulher", e que gesticulava, gritava e ensinava "sem ficar zangada, chorar de desespero ou arrancar os cabelos cor de palha." Simões, por sua vez, foi descrita como uma moça curiosa, viva e inteligente, que "nasceu para falar gesticulando, mandar em voz alta, fazer carranca de 'camera-man' italiano, envergar calças compridas e fumar com longas tragadas." No entanto, o que causou mais surpresa no jornalista foi o fato de que "elas pareciam estar à vontade. Era como se uma estivesse manejando um frasco de perfume e a outra dando gritinho à porta da casa, para chamar o irmão que jogava 'pelada' na rua”.

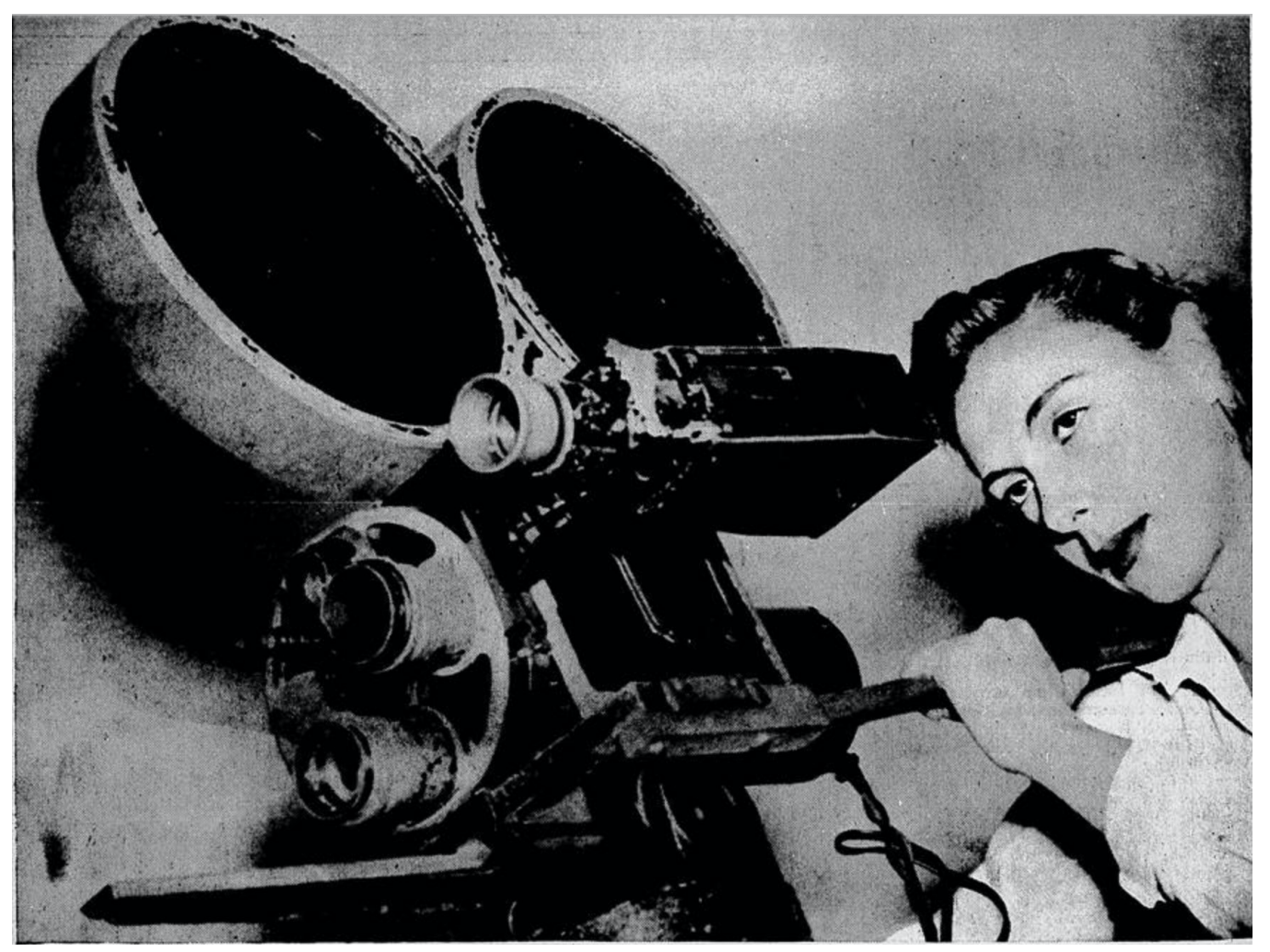

Imagem 3: Tânia Simões operando câmera no set de Estrada da Vida, Revista da Semana, 22 de março de 1952. | (C) Hemeroteca Digital Brasileira/Biblioteca Nacional

É curioso que, apesar das experiências prévias de O Mistério do Dominó Preto (1931), de Cléo de Verberena, Inconfidência Mineira (1949), de Carmen Santos, e dos notórios sucessos de Gilda de Abreu O Ébrio 
(1946), Pinguinho de Gente (1949) e Coração Materno (1951), produzidos poucos anos antes, a imprensa tenha considerado Simões como a primeira cineasta do Brasil e do mundo. A reverberação de tal chancela pode estar relacionada à estratégia de divulgação de Simões e Almeida como forma de atrair atenção para o filme e para a produtora, beneficiando-se da emergência de uma nova imagem da mulher brasileira influenciada pelas modas europeias, em voga no início dos anos $1950 .{ }^{21} \mathrm{~A}$ imediata adesão da imprensa revela que a ausência de mulheres no cinema era uma situação amplamente naturalizada e que bastava a presença de uma para celebração, favorecendo o esquecimento daquelas que a precederam. A existência das mulheres cineastas, cristalizada como curiosidade, está relacionada à vontade de noticiar aquilo que foge à regra, que é incomum. A contradição entre o recorrente espanto do público e da imprensa e a existência de diretoras ao longo da história do cinema brasileiro é mencionada no prefácio de Heloisa Buarque Hollanda (1989), sugerindo a reiteração dessa reação mista de surpresa e incredulidade diante da constatação de que as mulheres estavam lá, apesar da misoginia e da desigualdade de oportunidades.

Por outro lado, a fundação de uma produtora formada apenas por mulheres e o anúncio de uma mulher assinando a direção de fotografia de um longa-metragem podem ter sido os motivos da celebração na imprensa. Anteriormente, Cléo de Verberena havia sido sócia da EPICA-FILM ao lado de seu marido Cesar Melani (Araujo 2021, 14), assim como Carmen Santos teve contribuição de seu companheiro, Antônio Lartigau Seabra, para fundação da Brasil Vita Filmes (Pessoa 2002). Por fim, os filmes de Gilda de Abreu eram produzidos pela Cinédia de Adhemar Gonzaga (Pizoquero 2006).

Junto com a celebração do canhestro pioneirismo de Simões e Almeida, a "ideia arrojada"22 de mulheres dirigindo filmes no Brasil era colocada

\footnotetext{
${ }^{21}$ Influência desta postura pode ser notada pela presença de Simões Caldeira, como representante da Terras do Brasil, na comissão de recepção à aviadora Ada Rogato que celebrava exatamente a imagem desta nova mulher. Rogato foi a única aviadora do mundo, até 1951, a cobrir uma extensão de $51064 \mathrm{~km}$ em voo solitário pelas três Américas, chegando até o Alasca num trajeto que levou aproximadamente seis meses. Correio Paulistano, 21 de novembro de 1951, p. 7. Disponível em: http://memoria.bn.br/DocReader/DocReader.aspx?bib=090972 $\quad$ 10\&Pesq=\%22T\%c3\%a2nia\%20Sim\%c3\% $\underline{\mathrm{b} 5 \mathrm{es} \% 22 \& \text { pagfis }=8732}$

22 “Jovem Cineasta pretende fundar a Escola de Cinema”, Jornal de Notícias, 15 de setembro de 1951, p. 10. Disponível

em:
} 
à prova pela imprensa de forma reiterada, sobretudo devido ao porte pequeno da empresa produtora. Foi noticiado que "quando a dupla resolveu fazer cinema muita gente achou graça”. ${ }^{23}$ No entanto, elas seguiram reafirmando a capacidade artística e de realização de sua pequena companhia exclusivamente feminina perante os grandes estúdios:

Elas não temem as grandes companhias concorrentes e se arriscamos alguma pergunta maliciosa, que envolva capitais e maiores meios materiais, elas respondem simplesmente: 'Vá ver o filme. As bilheterias responderão sua pergunta e os críticos também. ${ }^{24}$

Ainda em contraposição à lógica dos grandes estúdios, Simões afirmou que buscaria jovens atores e atrizes que não tivessem sofrido "influências estranhas", referenciando diretamente o Neorrealismo italiano. De acordo com a própria, seriam jovens que com ela iniciariam "o movimento que Vittorio de Sica introduziu na Itália, o 'antiestrelismo'. ${ }^{25}$ Para Simões, a cooperação destes jovens e entusiastas era "um dos princípios básicos adotados para o êxito da confecção da película", além de contrariar "os processos usuais, fugindo aos moldes dos canastrões do cinema". ${ }^{26} \mathrm{O}$ elenco, constituído em sua maioria por comerciários que trabalhavam de dia e iam aos estúdios de noite e aos finais de semana para ensaiar e filmar, não receberia salário, mas, em troca, teriam coparticiparão dos lucros do filme. ${ }^{27}$ Segundo Simões, "ninguém se importava, pois não havendo salário, o remédio era sacrificar-se, esperando que o filme se tornasse um sucesso de bilheteria”. ${ }^{28}$

Numa de suas primeiras declarações à imprensa, Simões afirmou que, com uma porcentagem dos lucros do filme, tinha o objetivo de fundar

http://memoria.bn.br/DocReader/DocReader.aspx?bib=583138\&pesq=\%22T\%C3\%A2nia\%20Sim\%C3\%B5 es\%22\&pasta $=$ ano\%20195\&pagfis $=18567$

${ }^{23}$ Domingos de Lucca JR., "Mulheres descobrem a 7 a Arte".

${ }^{24}$ Idem.

25“Jovem Cineasta pretende fundar a Escola de Cinema".

${ }^{26}$ Idem.

${ }^{27}$ Domingos de Lucca JR., "Mulheres descobrem a 7 a Arte".

${ }^{28}$ Idem.

aniki A Pesquisa Histórica no Cinema Ibero-americano | Historical Research in Ibero-American Cinema 
uma escola de cinema para formação de técnicos e artistas, onde ela mesma ministraria um curso dramático. ${ }^{29}$ Vale ressaltar que, durante os anos 1950, empresas como a Vera Cruz e a Multifilmes compartilhava do ideal de se tornar uma escola de cineastas (Catani 2002). Este discurso difundido no meio cinematográfico servia há algumas décadas como uma prática corrente no cinema brasileiro, sendo talvez o exemplar mais notável o caso de José Mojica Marins (Senador 2008). Tais escolas duravam pouco tempo e serviam como meio para que cineastas e aspirantes conseguissem reunir recursos materiais, financeiros e profissionais para seus filmes. Apesar de combatida pelos críticos de cinema, essa prática conhecida como "cavação" desempenhou um importante papel de impulso no setor cinematográfico, ao mesmo tempo que revelava, nas palavras de Maria Rita Galvão, "uma compreensão muito clara das escassas possibilidades que o meio oferecia para a produção de filmes” (Senador 2008, 36).

A escassez do meio cinematográfico do período transparece nas reportagens, em que se registra que, além de enfrentarem o descrédito pela "arrojada empresa" dirigida por mulheres, Simões e Almeida tinham que lidar com comentários dos que não acreditavam no cinema nacional. Esse era um sentimento que se traduzia nos comentários céticos de "que [dada] a recente lei que obrigava as salas de projeção a passar um filme nacional para cada oito importados, a corrida de aventureiros sem escrúpulos toma vulto". ${ }^{30}$ Neste espírito popularesco, uma das reportagens de caráter sensacionalista encerra-se com tom desafiador:

A respeito da presente película o escândalo é maior, pois há quem não acredite nas mulheres atuando em cargos de tanta responsabilidade, como o de produtoras e diretoras cinematográficas. Contudo, espero que Tânia e Jovita não me desapontem, pois já fiz uma reportagem sobre mulheres que tem profissões de homens e as desempenham corretamente. A 'equipe' terá que mostrar ao Brasil se 'braço é braço' mesmo para não perdermos, cada vez mais, a fé na honestidade dos nossos patrícios que são diretores, artistas, cenaristas, ou 'camera-man'. Tânia e Jovita, as primeiras diretora e 'camera-girl' brasileiras, todavia, prometem sérias surpresas para os cineastas do país, afirmando que tudo sairá bem e que muitos dos nomes lançados nesse

\footnotetext{
29 "Jovem Cineasta pretende fundar a Escola de Cinema".

${ }^{30}$ Domingos de Lucca JR., "Mulheres descobrem a 7a Arte".
} 
primeiro filme já tem seu lugar reservado para brilhar na nascente constelação cinematográfica brasileira. Será?"31

\section{Estrada da Vida (1952)}

Contrariando a divulgação da imprensa de que a Cinematográfica Terras do Brasil contava "exclusivamente com elementos femininos, para suas produções", ${ }^{32}$ a ficha técnica de Estrada da Vida no acervo da Cinemateca Brasileira apresenta apenas nomes masculinos. ${ }^{33}$ As funções de direção de fotografia (César Giorgi), sonografia (Léo Racanelli), montagem (Gerard George), cenografia (George Montiel) e música (Lúcio Adolar) trazem nomes de técnicos iniciantes no momento de produção do filme, com pouca ou nenhuma experiência de trabalho em longas-metragens. À exceção do diretor de fotografia, César Giorgi, com breve experiência como assistente de fotografia em produções da Maristela, os outros nomes indicados haviam atuado em funções diferentes daquelas que exerceram em Estrada da Vida, não possuindo, assim, experiência prévia. ${ }^{34}$ Ainda que consideremos a inconsistência de dados do audiovisual brasileiro, é intrigante pensar nesta composição de equipe do único filme de uma produtora "constituída só de mulheres". ${ }^{5}$

A julgar pelas funções indicadas na ficha técnica e pelo anúncio na imprensa sobre o término das filmagens, ${ }^{36}$ é possível inferir que o filme tenha avançado até à etapa de montagem, contando, inclusive, com composição de música original. As fontes utilizadas pela Cinemateca Brasileira foram três reportagens: Folha da Noite (03/12/1951); Folha da Manhã (19/02/1952); e O Tempo (21/02/1952); além do texto

\footnotetext{
${ }^{31}$ Idem

32 "As mulheres comandam o cinema!", Carioca, 7 de fevereiro de 1952, p. 68-71. Disponível em: http://memoria.bn.br/DocReader/DocReader.aspx?bib=830259\&Pesq=\%22T\%c3\%a2nia\%20Sim\%c3\%b5es $\% 22 \&$ pagfis $=52320$

${ }^{33}$ Disponível em: http://bases.cinemateca.gov.br/cgi-

bin/wxis.exe/iah/? IsisScript=iah/iah.xis\&base=FILMOGRAFIA\&lang=P\&nextAction=search\&exprSearch= $\underline{\mathrm{ID}=017234 \& \text { format }=\text { detailed.pft }}$

${ }^{34}$ Antes de Estrada da Vida (1951), César Giorgi foi responsável pela direção de fotografia de Susana e o Presidente (1951), Presença de Anita (1951), e O Saci (cujas filmagens duraram de 1951 a 1953); e A Curra (1964, curta documentário).

35 “Cinema Brasileiro". A Cena Muda. 13 de março de 1952, nº11, p. 10. Disponível em: http://memoria.bn.br/DocReader/DocReader.aspx?bib=084859\&pesq=\%22T\%C3\%A2nia\%20Sim\%C3\%B5 es\%22\&pasta $=$ ano $\% 20195 \&$ pagfis $=56131$

${ }^{36}$ Domingos de Lucca JR., "Mulheres descobrem a 7a Arte".
} 
inédito de Maria Rita Galvão (197-), que registrou o início das filmagens em junho de 1952 e relacionou o filme como uma das produções em andamento naquele ano.

No entanto, os registros na imprensa indicam que o filme teria começado a ser rodado em meados de setembro $1951 .{ }^{37}$ No início de dezembro de 1951, uma pequena nota publicada no jornal Tribuna da Imprensa registra o fim das filmagens. ${ }^{38}$ Contudo, estas podem ter se prolongado até janeiro de 1952, como noticiou o Correio Paulistano, ao publicar que as últimas cenas estavam sendo filmadas e que o filme estaria pronto para exibição dentro de um mês, ou seja, em fevereiro de 1952. ${ }^{39}$ Três notas, publicadas neste ano, afirmam que o roteiro foi completamente filmado e sugerem que o filme foi finalizado. Uma delas trouxe a informação de que o filme seria distribuído pela distribuidora Publi-Filme; ${ }^{40}$ outra se reportou ao evento das filmagens de Estrada da Vida no passado, destacando que Simões "conseguiu focalizar cada uma das personagens, envolvê-las corretamente na continuidade do filme." ${ }^{41}$

Uma última menção do filme na imprensa, em junho de 1952, afirma que o mesmo está sendo terminado. ${ }^{42}$

$\mathrm{Na}$ ausência do material fílmico, as fontes jornalísticas revelam que o filme contava com seis protagonistas e vinte e seis figurantes em seu elenco, todos novatos porém, de acordo com a imprensa, apontados em

\footnotetext{
37 “Cinema da Mulher para os Dois Sexos”, Diário da Noite, 17 de setembro de 1951, p. 6. Disponível em http://memoria.bn.br/DocReader/DocReader.aspx?bib=093351\&pesq=\%22T\%C3\%A2nia\%20Sim\%C3\%B5 es\%22\&pasta=ano\%20195\&pagfis $=22040$, além de outras notas sobre a realização do filme que foram publicadas em $O$ Fluminense, 18 de setembro de 1951, p. 1. Disponível em

http://memoria.bn.br/DocReader/DocReader.aspx?bib=100439 09\&pesq=\%22T\%C3\%A2nia\%20Sim\%C3 \%B5es\%22\&pasta=ano\%20195\&pagfis=1826, e no Correio Paulistano, em 2 de outubro de 1951, p. 6 . Disponível

http://memoria.bn.br/DocReader/DocReader.aspx?bib=090972 10\&Pesq=\%22T\%c3\%a2nia\%20Sim\%c3\% b5es\%22\&pagfis $=8076$

38 "Empresa Cinematográfica só de Mulheres", Tribuna da Imprensa, 1-2 de dezembro de 1951, p.5. Disponível em: http://memoria.bn.br/DocReader/DocReader.aspx?bib=154083 01\&Pesq=\%22T\%c3\%a2nia\%20Sim\%c3\% b5es\%22\&pagfis $=6940$

39 "Visita o Correio Paulistano o pessoal do filme ‘Estrada Proibida”, Correio Paulistano, 3 de janeiro de 1952, $\quad$ p. $7 . \quad$ Disponível em: http://memoria.bn.br/DocReader/DocReader.aspx?bib=090972 10\&Pesq=\%22T\%c3\%a2nia\%20Sim\%c3\% b5es\%22\&pagfis $=9301$

40 "O Belo Sexo invade o cinema."

41 "As mulheres comandam o cinema!"

42 "Estréias do Cinema Brasileiro". A Noite, 19 de junho de 1952. Disponível em http://memoria.bn.br/pdf/348970/per348970 1952 14124.pdf
}

aniki A Pesquisa Histórica no Cinema Ibero-americano | Historical Research in Ibero-American Cinema 
São Paulo como "sensacionais revelações". ${ }^{43}$ É interessante destacar que os atores eram nomeados na imprensa com os nomes das personagens e que a abordagem ao elenco era inspirada na tendência do star-system estadunidense, apesar de Simões ter afirmado que preferia um elenco de novatos tal como nos filmes do Neorealismo Italiano. Eram parte do elenco principal Roque Cain, Eduardo Amaral, Samuel de Toledo, Marcos Fernandes, Lia de Moura, Maryland, e Cléa Tibiriçá. Juntos, figuraram em fotografias amplamente divulgadas com textos que ressaltavam seus atributos físicos. O ator Roque Cain foi chamado de "Clark Gamble brasileiro", enquanto as atrizes eram adjetivadas com predicados como "lourinha sensacional". ${ }^{44}$

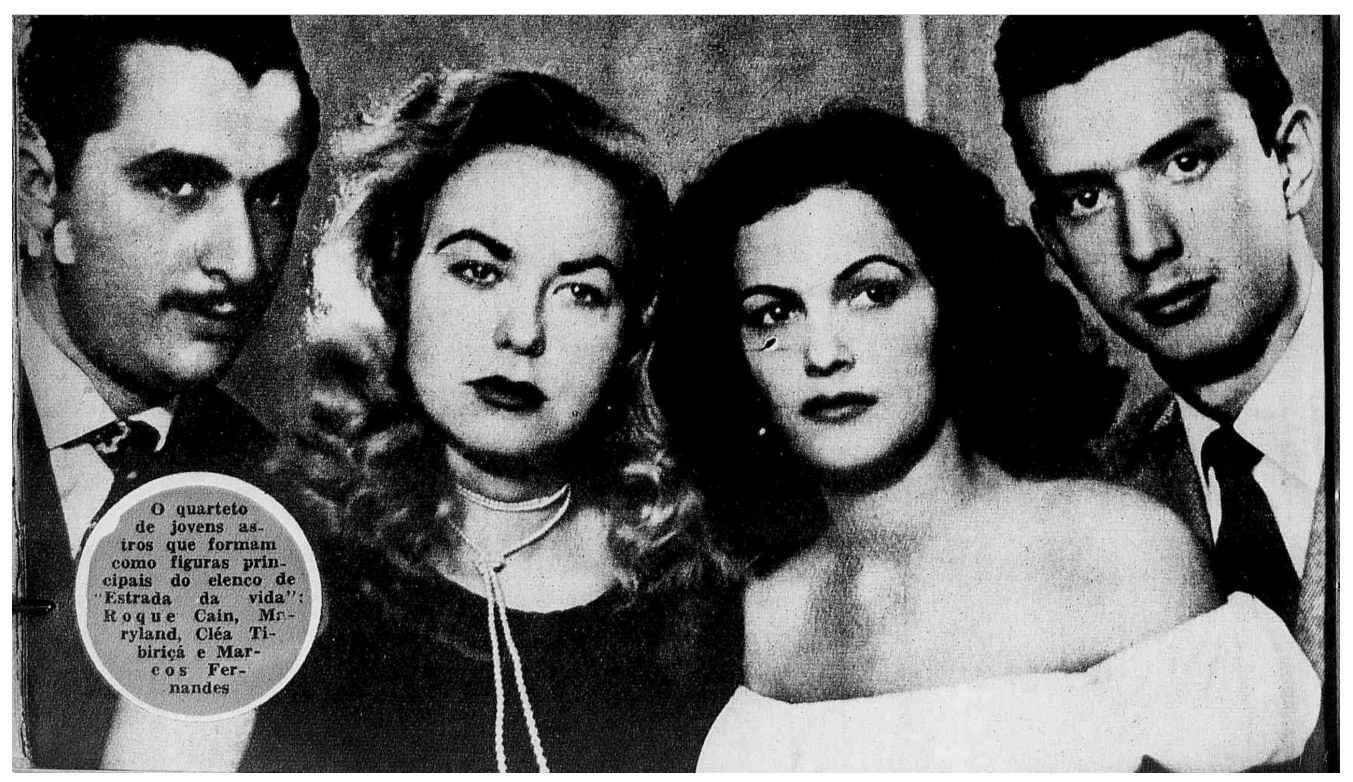

Imagem 4: Roque Cain, Maryland, Cléa Tibiriça e Marcos Fernandes, Carioca, 7 de fevereiro de 1952. | C Hemeroteca Digital Brasileira/Biblioteca Nacional

As fotografias posadas dos atores ou os registros dos sets divulgados na imprensa, no entanto, pouco aprofundaram sobre o roteiro do filme. Frases genéricas como uma "história de seis vidas, cada uma com seus dramas próprios" ${ }^{45}$ e "comovente, destinada a agradar ao grande

\footnotetext{
43 “As mulheres comandam o cinema!", Carioca, 7 de fevereiro de 1952, p. 68-71. Disponível em: http://memoria.bn.br/DocReader/DocReader.aspx?bib=830259\&Pesq=\%22T\%c3\%a2nia\%20Sim\%c3\%b5es \%22\&pagfis $=52320$

${ }^{44}$ Idem.

45 "As mulheres comandam o cinema!"
} 
público, montada com cenários luxuosos, história que se desenrola em São Paulo, no Rio e numa fazenda do interior" ${ }^{46}$ não revelam muito. Apesar disso, indicam certa dispersão narrativa, em vez do foco num casal de protagonistas ou num herói ou heroína, assim como dispersão de locações, indicando que era uma produção vultuosa.

De acordo com o roteiro do Estrada da Vida, localizado no arquivo da Sociedade Brasileira de Autores e Artistas de Teatro (SBAT), o filme trata-se da adaptação de um romance ${ }^{47}$ de Dirza Simões Diniz para o cinema, com a palavra 'drama' escrita logo abaixo do título. Apesar de, em conformidade com a divulgação, conter uma narrativa rocambolesca com a história de seis personagens intercaladas em diversas camadas temporais, o roteiro é um documento de parcas trinta e cinco páginas - considerado curto para o padrão de longas-metragens, sobretudo para um filme que se propõe a contar a história de seis vidas.

As páginas do roteiro de Estrada da Vida contam a história da paixão proibida entre Maryland e Marcos, impedida por um segredo familiar que a moça herdou de seu pai, Eduardo. Narrada por Samuel, um amigo de Roque Caim, pai de Marcos, a narrativa se desenrola em flashbacks que explicam o passado das personagens. Marcos é fruto da traição de Lia, primeira esposa de Eduardo, com Roque. Eduardo mata Lia, mas não consegue matar o filho dela e, por isso, em seu leito de morte, pede à filha que herde esta vingança e conclua seu plano de assassinar o rapaz. Ao acaso, Maryland se apaixona por Marcos e, quando descobre que ele é o filho de Roque, fica dividida entre o amor por Marcos e a missão herdada do pai.

O conteúdo revela uma narrativa protagonizada pela jovem Maryland, na qual estão presentes vários aspectos que caracterizam o gênero do melodrama, como enredo centrado em conflitos amorosos e familiares, com muitas passagens de intensidade emocional. O conflito principal, vivido pela protagonista, coloca, de um lado, a vida amorosa e, do outro, o compromisso familiar. No entanto, embora a polaridade moral (vilania $\mathrm{x}$ virtude) esteja presente na narrativa e o desfecho do filme confirme a superioridade moral da virtude, há espaço para que a heroína abdique do cumprimento de sua herança maldita. Essa recusa

\footnotetext{
46 "Cinema da Mulher para os Dois Sexos".

${ }^{47}$ Não foram encontradas evidências de que este romance tenha sido publicado.
} 
da herança familiar demonstra certa agência dos rumos de sua vida. $\mathrm{O}$ mesmo se pode dizer das restantes personagens femininas. Apesar de, a princípio, se tratar de uma narrativa movida pela sede de vingança de um homem (Eduardo) que se sente "desonrado" com a traição da esposa, as personagens femininas apresentam-se como mulheres emancipadas. Uma delas é Lia, cuja história é contada através do recurso a flashback. Apesar de ter se casado com Eduardo para agradar os pais, mantém sua profissão como cantora da noite e se apaixona por Roque, com quem trama um plano para fugir, antes de ser assassinada pelo ex-marido. Maryland, por sua vez, é uma jovem universitária, que vive com a mãe adotiva Dona Júlia, viúva de Eduardo, e cursa faculdade no Rio de Janeiro. Sua trama é desenvolvida no tempo presente do filme. Dona Júlia é uma mulher independente que vive sem homens ao seu redor, apesar de manter amizade com alguns.

Os homens, por outro lado, parecem ser as forças motrizes das desgraças presentes na narrativa. Antes de se apaixonar e fugir com Lia, Roque abandona Cléa, sua noiva, história essa também contada através de flashback. Com sua boa condição financeira, Eduardo força o casamento com Lia, a mata quando descobre sua fuga e promete ainda matar o filho que ela tivera com o amante. Dr. Raul é um médico decrépito e corrupto que, em troca de um casamento arranjado para sua filha Suzana, revela a Eduardo o endereço de Lia, para que este possa vingar sua honra ferida. Samuel, o narrador aparentemente isento, pressiona Dr. Raul para saber o paradeiro de Eduardo após o feminicídio, ameaçando matar sua neta recém nascida, filha de Suzana e Eduardo. A única exceção é o jovem Marcos, representante da nova geração, cujas virtudes destoam da masculinidade-padrão da época. No primeiro encontro com Maryland, ela nota que ele tem aptidão para os afazeres domésticos, algo que era, naquela época, designado quase que exclusivamente às mulheres.

Os efeitos de simbolização, outra marca do melodrama (Baltar 2005), se fazem presentes na função do pequeno livro que Maryland carrega consigo por toda trama como símbolo da herança maldita que recebeu do pai. O objeto contribui de maneira estratégica tanto para estabelecer o conflito principal quanto para conduzir a resolução da narrativa que tem, no entanto, um desfecho simplório e óbvio: Maryland se livra da herança maldita ao descobrir que Eduardo não era seu verdadeiro pai, e assim fica moralmente liberada para se casar com Marcos. 


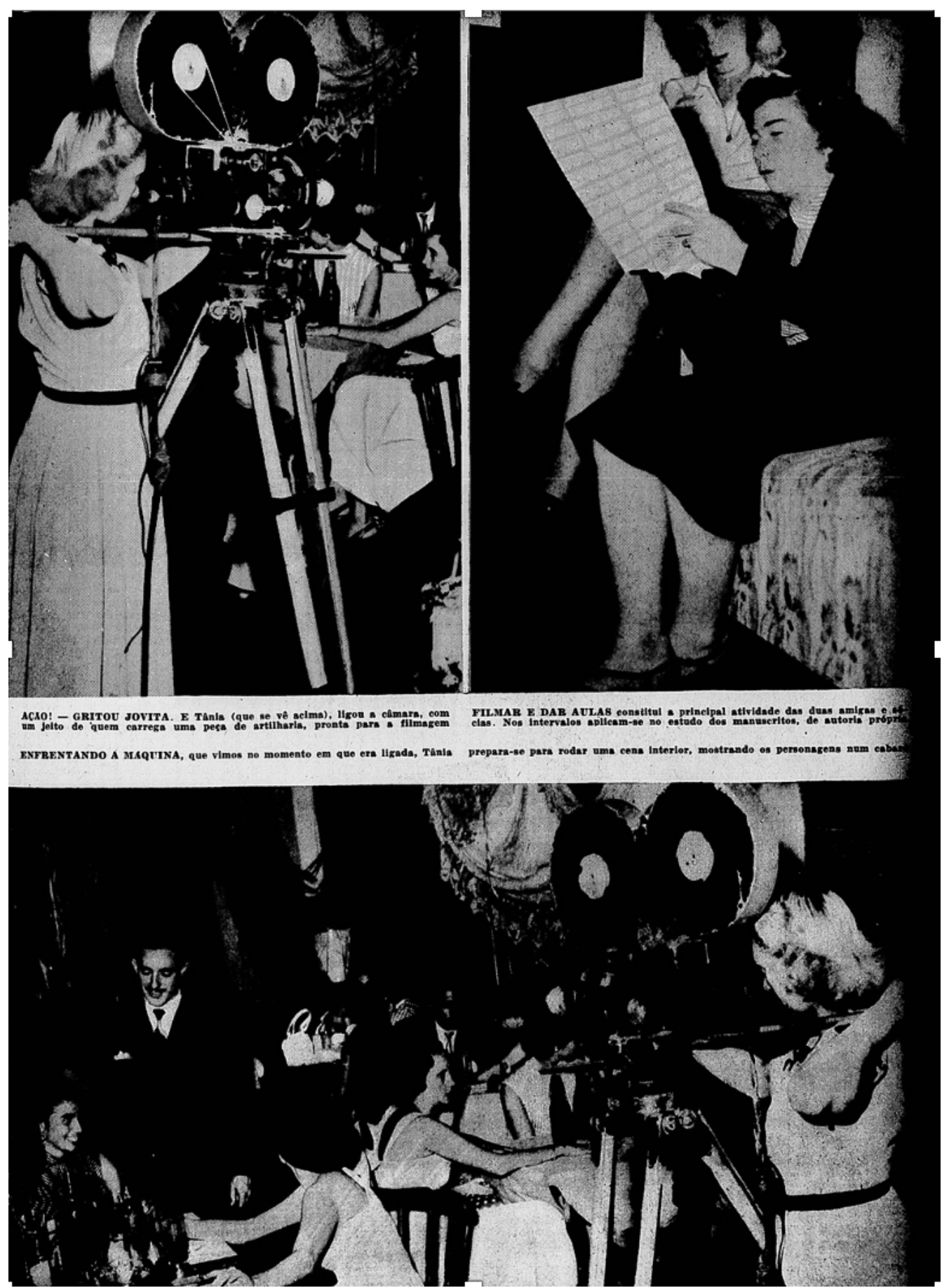

Imagem 5: Fotografias do set Estrada da Vida, Revista da Semana (RJ). | @ Hemeroteca Digital Brasileira/ Biblioteca Nacional.

A partir de 1953, as menções na imprensa a respeito de Tânia Simões, Jovita de Almeida, Estrada da Vida e a Cinematográfica Terras do Brasil desapareceram da mesma forma abrupta com que surgiram. Sem o lançamento, o filme permaneceu com a pecha de inacabado. Não há 
evidências na base de dados da Cinemateca Brasileira de que Tânia Simões e Jovita de Almeida tenham tentado realizar outro longametragem. Por outro lado, a pesquisa sobre Almeida no acervo SBAT revela a existência de um argumento cinematográfico de dez páginas, intitulado $A$ mulher que eu amei, bem como um folheto de curtametragem e texto para cinema de oito páginas, intitulado $\mathrm{Na}$ calada da madrugada, sugerindo que a produtora tinha outros projetos em curso.

\section{Retomada no teatro carioca}

A partir de 1954, após o malogro no cinema, Simões e Almeida se mudaram para o Rio de Janeiro onde atuaram no meio teatral através da companhia D.I.A.N.E. (Divulgação Independente de Artistas Nacionais e Estrangeiros), posteriormente transformada na Empresa Teatral e Cinematográfica Guanabara. Neste período, Almeida se associou à Sociedade Brasileira de Autores Teatrais ${ }^{48}$ e passou a utilizar o nome artístico de Viviane Hidalgo. Ela atuava como dramaturga e diretora enquanto Simões, que passou identificar-se como Sônia Sandra, se tornou produtora e empresária teatral.

Entre 1954 e 1958, Simões e Almeida encenaram três peças escritas ${ }^{49}$ por Hidalgo (Almeida), cujos atores eram os alunos de uma escola de atuação registrada sob o nome da Cinematográfica Terras do Brasil, um arranjo próximo ao que almejaram estabelecer no cinema. Da mesma maneira, alguns dos textos teatrais de autoria de Hidalgo apresentam carimbo da Cinematográfica Terras do Brasil. As peças da D.I.A.N.E., e sobretudo Hidalgo (Almeida), foram alvo de duras críticas dos colunistas Oscar Nimtzovitch, do Correio Paulistano, e Oscar Henrique, do Diário de Notícias. Identificadas como as "conhecidíssimas Tânia e Jovita", os jornalistas acusam ambas de terem sido processadas por atores de uma de suas peças. Em suas notas, Nimtzovitch ironizou o título da peça Essa mulher é um perigo afirmando que tanto Hidalgo

\footnotetext{
${ }^{48}$ Última Hora, 18 de janeiro de 1954, p. 3. Disponível em: http://memoria.bn.br/DocReader/DocReader.aspx?bib=386030\&pesq=\%22Jovita\%20de\%20Almeida\%22\& pasta $=$ ano $\% 20195 \&$ pagfis $=17235$

${ }^{49} \mathrm{O}$ roteiro das peças pode ser encontrado no acervo da Sociedade Brasileira de Autores Teatrais (SBAT).
} 
como Sandra eram perigosas e esquisitas, remetendo à esquisitice (queerness) das artistas. ${ }^{50}$

O cronista Mattos Pacheco se uniu aos críticos de Hidalgo numa discussão pública que culminou numa carta da autora ao jornal Diário da Noite, ${ }^{51}$ na qual reclamava dos ataques diários com injúrias e difamação que ela e a escola administrada pela Cinematográfica Terras do Brasil vinham sofrendo. Em resposta, o colunista rebateu a carta criticando a ortografia do conteúdo, o valor de registro de cachê de artistas e cobrando a apresentação do Registro de Escola Dramática, acusando-a de funcionamento ilegal. Esta acusação remete ao funcionamento das escolas de atuação e, ainda que este tipo de acusações fosse comum no meio cinematográfico, o cronista não apresenta maiores detalhes ou testemunhas.

Dois anos depois, em 1956, quando a dupla resolveu retomar as atividades da D.I.A.N.E., com a estreia do espetáculo musical Realidade da Vida, que recebeu apenas dois elogios em meio a uma enxurrada de críticas negativas. Foram exaltados o elenco descoberto e ensaiado por Hidalgo, ${ }^{52}$ a perfeita cenografia e a ourivesaria luxuosa, ${ }^{53}$ enquanto os críticos se dirigiram sobretudo, mas não apenas, ao elenco iniciante. ${ }^{54}$

O espetáculo seguinte, intitulado Chi, Mademoiselle, Chi, repetiu a péssima recepção, sendo descrito como uma "comédiazinha de

\footnotetext{
${ }^{50}$ Oscar Nimtzovitch, "Notas e Novidades”, Correio Paulistano, 17 de junho de 1954, p. 7. Disponível em: http://memoria.bn.br/DocReader/DocReader.aspx?bib=090972 10\&pesq=\%22Jovita\%20de\%20Almeida\% 22\&pasta=ano\%20195\&pagfis=21986; e Oscar Nimtzovitch, "Notas e Novidades", Correio Paulistano, 7 de julho de 1954, 1 p. $7 . \quad$ Disponível http://memoria.bn.br/DocReader/DocReader.aspx?bib=090972 $\quad$ 10\&pesq=\%22Jovita\%20de\%20Almeida\% 22\&pasta $=$ ano $\% 20195 \&$ pagfis $=22174$

${ }^{51}$ Mattos Pacheco, "Ronda”, Diário da Noite, 5 de agosto de 1954, p. 15. Disponível em: http://memoria.bn.br/DocReader/DocReader.aspx?bib=093351\&pesq=\%22Jovita\%20de\%20Almeida\%22\& pasta $=$ ano $\% 20195 \&$ pagfis $=31952$

52 "Grandiosa e inédita 'avant-premiere' de gala, dia 28 do corrente, no Teatro Serrador às $21 \mathrm{hs",} 10$ de maio de 1956, p.4. Disponível em:

http://memoria.bn.br/DocReader/DocReader.aspx?bib=154083 01\&pesq=\%22Jovita\%20de\%20Almeida\% 22\&pasta $=$ ano $\% 20195 \&$ pagfis $=30595$

53 "Louvação a Diane", Tribuna da Imprensa (RJ), 1 de junho de 1956, p.4 Disponível em: http://memoria.bn.br/DocReader/DocReader.aspx?bib=154083 01\&Pesq=\%22Viviane\%20Hidalgo\%22\&p agfis $=28278$

${ }^{54}$ Aldo Calvet, "O desastre de DIANE no Serrador", Última Hora, 31 de maio de 1956, p. 4. Disponível em: http://memoria.bn.br/DocReader/DocReader.aspx?bib=386030\&Pesq=\%22Viviane\%20Hidalgo\%22\&pagfi $\underline{\mathrm{s}=30541}$
}

aniki A Pesquisa Histórica no Cinema Ibero-americano | Historical Research in Ibero-American Cinema 
equívocos". ${ }^{55}$ Um crítica classifica como "imperdoável o mau-gôsto na composição de certo personagem, já definido de modo deprimente no texto". ${ }^{56}$ Apesar da parcial ilegibilidade do texto digitalizado, há fortes indícios de que se trata de uma peça com personagens homossexuais. Essas e outras críticas negativas recaem sobre Hidalgo, mas escusam o codiretor Artur Rosa Mateus, diretor português do teatro de revista. Neste período, a mais dura crítica acusa Hidalgo de ter sido expulsa do meio teatral de São Paulo e de ter ido ao Rio de Janeiro para criar "a maior picaretagem dos últimos tempos em nosso teatro: o despontar de D.I.A.N.E.". ${ }^{57}$

O motivo para a fúria dos críticos pode estar, por um lado, relacionado ao preconceito estético com o qual olhavam o teatro de revista. ${ }^{58}$ Por outro lado, pode estar relacionado com a série de acusações publicadas por Ney Machado, no jornal A Noite, a partir de meados de setembro de 1956. ${ }^{59}$ Além de criticar os espetáculos, Machado acusava a empresa ser uma "arapuca" que tomava dinheiro dos alunos-candidatos, explorando a boa-fé e o desejo de jovens de ingressar no cinema. Entretanto, apesar das acusações públicas frequentes, apenas duas supostas vítimas se apresentaram para falar sobre o caso. Enquanto o ex-aluno Jaime Nogueira reclamava ter sido extorquido e contratado sem salário, apesar da promessa de uma alta soma, a arquiteta Dulce Campos contou ter perdido dinheiro depois de ter sido convidada para dirigir uma das peças da companhia. Vale notar que estes depoimentos enfatizaram "fatos condenáveis que dona Sandra e Viviane teriam tentado fazer com as moças lançadas como atrizes," em A Realidade da vida e Chi

\footnotetext{
55 "Volta da Diane numa nova tentativa ainda de precária qualidade artística", Jornal dos Sports, 9 de setembro de $1956, \quad$ p. $11 . \quad 10$ Disponível http://memoria.bn.br/DocReader/DocReader.aspx?bib=112518 02\&Pesq=\%22Viviane\%20Hidalgo\%22\&p $\underline{\text { agfis }=14578}$

${ }^{56}$ Arnaldo Vicente, "Teatro no Rio", O Cruzeiro, 15 de setembro de 1956, p. 123. Disponível em: http://memoria.bn.br/DocReader/DocReader.aspx?bib=089842 06\&Pesq=\%22Viviane\%20Hidalgo\%22\&p agfis $=79930$

${ }^{57}$ João Augusto, "Figuras e Fatos", Tribuna da Imprensa (RJ), 22-23 de setembro de 1956, p.4. Disponível em:

http://memoria.bn.br/DocReader/DocReader.aspx?bib=154083_01\&pesq=\%22Jovita\%20de\%20Almeida\% 22\&pasta $=$ ano $\% 20195 \&$ pagfis $=30595$

${ }^{58}$ As peças do teatro de revista caracterizam-se pelo apelo à sensualidade e pela sátira social e política, sendo muitas vezes compostas de esquetes intercalados por musicais e dança.

${ }^{59}$ Ney Machado, "Extorsão em nome do teatro e do cinema", A Noite, 14 de setembro de 1956, pp. 6 e 27. Disponível http://memoria.bn.br/DocReader/DocReader.aspx?bib=348970 05\&pesq=\%22Jovita\%20de\%20Almeida\% $22 \&$ pasta $=$ ano $\% 20195 \&$ pagfis $=38337$
} 
Mademoiselle Chi, revelando que o ódio pela dupla poderia ter origem em prerrogativas morais relacionadas à bissexualidade e/ou lesbianidade de Hidalgo e Sandra.

Essa é a primeira alusão à sexualidade da dupla e tanto o colunista como a testemunha associam diretamente a orientação sexual de Hidalgo e de Sandra aos supostos assédios cometidos, uma estratégia de difamação recorrente nos casos de homofobia. A acusação viria a ser desmentida pelo pai de uma das supostas vítimas, que procurou o jornal para dizer que "houve exagero no relato". ${ }^{60}$ Contudo, o colunista continuou os ataques públicos à dupla e, dias depois, noticiou que Dulce Campos apresentara queixa-crime contra a companhia, afirmando que, quando vira o que se passava lá dentro, retirara imediatamente sua filha daquele ambiente. ${ }^{61}$

Nem todas as críticas negativas afastaram a dupla do meio artístico e, no ano seguinte, em 1957, elas ocuparam um pequeno teatro no bairro Penha Circular, nos subúrbios do Rio de Janeiro. A partir de uma crítica gentil publicada no Correio da Manhã pelo crítico identificado como P.C.M., é possível saber que o grupo da Empresa Teatral e Cinematográfica da Guanabara havia "cuidado da reforma e da limpeza" do antigo teatro e que o próprio elenco havia se transformado em pintores, cenaristas, aderecistas, varredores de chão e de poeira para restauração daquele espaço importante como berço de novos talentos:

Conversando com esses quase-adolescentes, que Viviane Hidalgo e S. Sandra comandam, lembrei-lhes a importância dos arrabaldes longínquos, dos subúrbios de Londres. Das vezes que como milhares de outros, tomei trem subterrâneo, ônibus, fiz duas, três baldeações, para assistir a um espetáculo com gente da idade deles ou mais velha e já famosa, num desses palcos apertados e distantes. ${ }^{62}$

\footnotetext{
${ }^{60}$ Ney Machado, “Diane não pagou a Gessy Santos”, A Noite, 19 de setembro de 1956, pp. 3 e 27. Disponível em:

http://memoria.bn.br/DocReader/DocReader.aspx?bib=348970 05\&pesq=\%22Jovita\%20de\%20Almeida\% 22\&pasta $=$ ano $\% 20195 \&$ pagfis $=38430$

${ }^{61}$ Ney Machado, "Queixa-Crime contra a Diane”, A Noite, 22 de setembro de 1956, pp. 3 e 27. Disponível em:

http://memoria.bn.br/DocReader/DocReader.aspx?bib=348970 05\&Pesq=\%22Viviane\%20Hidalgo\%22\&p agfis $=38480$

62 “Teatro Penha Circular”, Correio da Manhã, 1 de agosto de 1957, p.15. Disponível em:

http://memoria.bn.br/DocReader/DocReader.aspx?bib=089842 06\&Pesq=\%22Viviane\%20Hidalgo\%22\&p agfis $=79668$
}

aniki A Pesquisa Histórica no Cinema Ibero-americano | Historical Research in Ibero-American Cinema 
Em 1958, elas ainda tentaram a sorte, mais uma vez, com a peça a Tem Água no Bikini, no teatro do Leme, mas igualmente receberam muitas críticas negativas. O teatrólogo Aldo Calvet classificou a estréia como "atrevimento das Sras Viviane Hidalgo e S. Sandra" e chamou o espetáculo de uma "revista medíocre, de monólogos insulsos e repetidos, de quadrinhos pifes, de esquetes pobres de hilaridade, velhos e cansados, repletos de intenções acentuadamente pornográficas, de cortinas vulgares". ${ }^{63}$ Por fim, as acusou de aplicarem "a fórmula mais violenta e contundente de lutar contra o teatro no Brasil, servindo-se de inocentes úteis (os profissionais) e de incautos ingênuos (os amadores e principiantes)", e reacendeu a polêmica da lesbianidade:

O pomo da discórdia nesta nova edição-diane parece ser Talita Guajarina que Dirza Simões Diniz (Sônia Sandra), por questões de interesse afetivo, entende apresentá-la como 'estrela'. A moça, na realidade não dispõe de qualidade artísticas, pois é apenas uma principiante bisonha, gozando tão somente das simpatias da empresária. (...) proteção estranha da D. Dirza Simões Diniz, a D. Sandra com relação a Talita Guajarina. (...) Estamos a reafirmar que Sandra e Hidalgo encontraram a fórmula mais violenta de lutar contra o teatro no Brasil. $^{64}$

A exposição a constrangimento público nas linhas dos críticos, que se utilizaram da orientação sexual das diretoras para massacrá-las publicamente, enquanto criticavam suas peças, indica o grande fardo gerado para Hidalgo e Sandra numa sociedade misógina e lesbofóbica. Qual teria sido o impacto destas críticas na trajetória das artistas? Seria possível mesurar os impedimentos que foram impostos a partir dessa exposição?

Após os reveses nos meios cinematográfico e teatrais, Simões e Almeida reinventaram suas personagens pela última vez, figurando

\footnotetext{
${ }^{63}$ Aldo Calvet, “Tem água no bikini, no Leme”, Última Hora, 20 de junho de 1958, p. 4. Disponível em: http://memoria.bn.br/DocReader/DocReader.aspx?bib=386030\&Pesq=\%22Viviane\%20Hidalgo\%22\&pagfi $\underline{\mathrm{s}=48761}$

${ }^{64}$ Aldo Calvet, “A Pique o 'ITA' \& Guanabara”, Última Hora, 4 de julho de 1958, p. 6. Disponível em: http://memoria.bn.br/DocReader/DocReader.aspx?bib=386030\&Pesq=\%22Viviane\%20Hidalgo\%22\&pagfi $\underline{s=49149}$
}

aniki A Pesquisa Histórica no Cinema Ibero-americano | Historical Research in Ibero-American Cinema 
deliberadamente nas páginas policiais. Com novos pseudônimos, fazendo pose de mulheres endinheiradas a bordo de um Cadillac, elas adquiriam bens a prazo em grandes magazines, mas nunca pagavam. ${ }^{65} \mathrm{~A}$ época, a polícia calculou que, ao todo, elas teriam ludibriado vinte e cinco lojas através de compras a crédito que não foram pagas. ${ }^{66} \mathrm{Em}$ 1961, Almeida foi acusada de furto, crime pelo qual foi condenada à revelia a um ano e seis meses de reclusão e, em 1963, ambas foram condenadas a um ano e dois meses de reclusão por estelionato. ${ }^{67} \mathrm{O}$ último registro de seus nomes localizado por esta pesquisa inicial consta num processo penal, no qual, além de terem sido acusadas e condenadas por estelionato, pesou decisiva e publicamente o estigma de que as duas eram lésbicas e de que, apesar de serem rés primárias, gozavam de "péssima reputação", expressão onde cabem inúmeras interpretações. ${ }^{68}$ Por esse último crime também foram condenadas à revelia, indicando que, à data do julgamento, haviam desaparecido no mundo.

\footnotetext{
65 "Conto do Crédito: Duas Vigaristas Aplicam golpe em Firma Comercial”, Última Hora (PR), 28 de janeiro de 1961, p. 2. Disponível em:

http://memoria.bn.br/DocReader/DocReader.aspx?bib=830348\&pesq=\%22Jovita\%20de\%20Almeida\%22\& pasta=ano\%20196\&pagfis=9139

66 “Três mulheres lesam comércio em CR\$ 3 milhões”, O Jornal, 2 de fevereiro de 1961, p. 9. Disponível em http://memoria.bn.br/DocReader/DocReader.aspx?bib=110523 06\&pesq=\%22Jovita\%20de\%20Almeida\% 22\&pasta=ano\%20196\&pagfis $=11219$

${ }^{67}$ Diário Oficial do Estado de São Paulo, Imprensa Oficial, Ano LXXI, no 110, 20 de maio de 1961 , p. 11. Disponível em: https://www.imprensaoficial.com.br/DO/BuscaDO2001Documento 11 4.aspx?link=\%2f1961\%2fjudiciari o\%2fmaio\%2f20\%2fpag 0011 AEEAVD14QL6DNeENLNDJPPI5BNJ.pdf\&pagina=11\&data=20/05/1961\&c aderno=Judici\%C3\%A1rio\&paginaordenacao=100011; Diário Oficial do Estado de São Paulo, Imprensa Oficial, Ano XXXIII, $\mathrm{n}^{\mathrm{o}}$ 152, 14 de agosto de 1963, p. 54. Disponível em: https://www.imprensaoficial.com.br/DO/BuscaDO2001Documento 11 4.aspx?link=\%2f1963\%2fjudiciari o\%2fagosto\%2f14\%2fpag 0054 1400DVIIOP8D3e5R333AMJ32QHB.pdf\&pagina=54\&data=14/08/1963\&c aderno=Judici\%C3\%A1rio\&paginaordenacao=100054; e Diário Oficial do Estado de São Paulo, Imprensa Oficial, Ano XXXI, $\mathrm{n}^{\mathrm{o}}$ 200, 6 de setembro de 1961, p. 42. Disponível em: https://www.imprensaoficial.com.br/DO/BuscaDO2001Documento 11 4.aspx?link=\%2f1961\%2fjudiciari o\%2fsetembro\%2f06\%2fpag 0042 4NRU5JEII6QFSe0QDGKR6THL48N.pdf\&pagina=42\&data=06/09/196 1\&caderno=Judici\%C3\%A1rio\&paginaordenacao=100042 (acessados em 10/08/2021).

${ }^{68}$ Diário Oficial do Estado de São Paulo. Imprensa Oficial, no 63, Ano XXXIII, 03/04/1963, p. 49, Disponível em

https://www.imprensaoficial.com.br/DO/BuscaDO2001Documento 11 4.aspx?link=\%2f1963\%2fjudiciari o\%2fabril\%2f03\%2fpag 0049 79LV66NOKCOUSeDIKSOPKU7V0SU.pdf\&pagina=49\&data=03/04/1963\&c aderno=Judici\%C3\%A1rio\&paginaordenacao=100049 Acessado em 10/08/2021.
}

aniki A Pesquisa Histórica no Cinema Ibero-americano | Historical Research in Ibero-American Cinema 


\section{Considerações finais}

A investida de Tânia Simões e Jovita de Almeida no cinema aconteceu no início dos anos 1950, período no qual a alta inflação e o tabelamento do preço do ingresso de cinema foram decisivos para a falência das produtoras paulistas e da indústria cinematográfica nacional, que não sobreviveria sem a legislação protecionista (Galvão 1981; Simis 2010). Havia, naquele momento, grande expectativa de mudanças no setor a partir da organização da classe cinematográfica. Conscientes desta mobilização, as publicações na imprensa sugerem que Simões participou do I Congresso Paulista de Cinema Brasileiro.

Em meio a um cenário dominado por grandes estúdios que buscavam estabelecer uma indústria cinematográfica em São Paulo e por realizadores independentes, homens que procuravam formas alternativas diante das impossibilidades materiais de produção (Catani 2018), a dupla partiu para uma estratégia ambiciosa: tanto nos planos de realização de um longa-metragem de ficção, quanto na divulgação na imprensa, após uma breve experiência em cinejornais, conforme apontam os registros.

Tendo sua capacidade confrontada pela imprensa de forma misógina, por serem mulheres que estariam se aventurando em funções supostamente masculinas e propondo modelos alternativos de produção, baseados na cooperação em equipe, e somado o preconceito dos críticos com relação ao que se chamou de "cavação", as declarações contundentes da dupla Simões e Almeida - bem como as fotografias operando câmeras de $35 \mathrm{~mm}$ - podem ser tomadas como um importante ponto simbólico na reflexão sobre a continuidade e descontinuidade da presença de mulheres diretoras no cinema brasileiro, sobretudo no período específico. Vale registrar que, ainda que tudo não tenha passado de uma experiência fantasiosa e/ou frustrada - o que parece ser o caso -, o ato de criar uma produtora de mulheres, comparecer às reuniões de classe, divulgar na imprensa essa informação incômoda e marcar a presença desconfortável onde nem sempre há espaço, contribuiu para que a sociedade pensasse sobre a possibilidade de mulheres empunhando câmeras e filmando suas ideias.

Com relação ao massacre na imprensa carioca, que considerava vulgares os elementos kitsch dos roteiros de Hidalgo e associava a bissexualidade ou lesbianidade das autoras para corroborar acusações de golpe e assédio, é necessário aprofundar as pesquisas para confirmar se tais acusações encontraram eco também nos críticos de cinema. 
Neste caso, seria de considerar a experiência frustrada de Alberto Cavalcanti, declaradamente homossexual, à frente da Vera Cruz (Cavalcanti 1957), ainda que esta seja uma passagem carente de maior investigação nos estudos de cinema no Brasil.

\section{Agradecimentos}

Este artigo não existiria sem a contribuição preciosa dos pesquisadores Alberto de Oliveira e Alberto Camarero, a quem agradeço por me apresentarem as figuras de Tânia Simões e Jovita de Almeida.

\section{Referências}

Andrade, Regina. 1997. "A sombra de uma estrela - Carla Civelli". Revista Logos $4 \quad 4 \quad$ (2). publicacoes.uerj.br/index.php/logos/article/view/14600/11063 (acessado em 02/02/2021).

Araujo, Marcella. 2021. Cleo de Verberena: Cineasta brasileira. Tese de Doutorado. São Paulo: Escola de Comunicações e Artes, Universidade de São Paulo. https://doi.org/10.11606/T.27.2021.tde-26082021-123104.

Autran, Arthur. 2013. O Pensamento Industrial Cinematográfico Brasileiro. São Paulo: Hucitec Editora. . 2003. Alex Viany: Crítico e Historiador. São Paulo: Editora Perspectiva.

Baltar, Mariana. 2005. "Metáforas à flor da pele - Os excessivos símbolos que antecipam nossa comoção”. Contracampo - revista de Cinema, v. 71: 71.

Catani, Afrânio. 2002. A sombra da outra: a cinematográfica Maristela e o Cinema Industrial Paulista nos anos 50. São Paulo: Panorama. . 2018. "Vera Cruz e os estúdios paulistas nos anos 1950”. Em: Nova História do Cinema Brasileiro, organizado por Fernão Pessoa Ramos e Sheila Schvarzman, v.1, 454-487. São Paulo: Edições Sesc.

Cavalcanti, Alberto. 1957. Filme e Realidade. Rio de Janeiro: Casa do Estudante do Brasil. 
Costa, Flavia Cesarino e Canepa, Laura. 2018. "O cinema paulista para além dos estúdios”. Em: Nova história do cinema brasileiro, organizado por Fernão Pessoa Ramos e Sheila Schvarzman, v.1, 454-487. São Paulo: Edições Sesc.

Galvão, Maria Rita. 197-. Origens do Cinema Independente de São Paulo. São Paulo: manuscrito inédito, depositado na Cinemateca Brasileira.

1981. Burguesia e Cinema: O Caso Vera Cruz. Rio de Janeiro: Editora Civilização Brasileira.

Hollanda, Heloisa Buarque. 1989. Quase Catálogo: Realizadoras de cinema no Brasil: (1930/1988). Rio de Janeiro: CIEC.

Munerato, Elice e Oliveira, Maria Helena Darcy. 1982. As musas da matinê. Rio de Janeiro: Edições Rioarte.

Pereira Jr, Araken. 1979. Cinema Brasileiro (1908-1978) - Longametragem. V.1: 1908-1968. Santos: Casa do Cinema.

Pessoa, Ana. 2002. Sob a Luz das Estrelas: Relembrar Carmen Santos. Fundação Casa Rui Barbosa. São Paulo: Centro Cultural São Paulo.

Poppi, Roberto. 2002. I registi dal 1930 al giorni nostri. Roma: Gremesse.

Pizoquero, Lucilene. 2006. Cinema e genero: a trajetoria de Gilda de Abreu (1904-1979). Dissertação de mestrado. São Paulo: Universidade Estadual de Campinas, Instituto de Artes. Disponível em: http://www.repositorio.unicamp.br/handle/REPOSIP/284770

Salles Gomes, Paulo Emílio. 1996. Cinema: Trajetória no Subdesenvolvimento. Rio de Janeiro: Paz e Terra.

Senador, Daniela 2008. Das primeiras experiências ao fenômeno Zé do Caixão: um estudo sobre o modo de produção e a recepção dos filmes de José Mojica Marins entre 1953 e 1967. Dissertação de mestrado. São Paulo: Escola de Comunicações e Artes, Universidade de São Paulo. $\quad$ https://doi.org/10.11606/D.27.2008.tde-05072009230157.

Simis, Anita. 2010. "Cinema e política cinematográfica”. Em: Economia da Arte e da Cultura, editado por César Bolaño, Cida Golin e Valério Brittos, 137-164. São Paulo: Itaú Cultural. 


\section{Filmografia}

Estrada da Vida [longa-metragem, inacabado]. Dir. Tânia Simões. Cinematográfica Terras do Brasil, Brasil, 1952.

\section{Estrada da Vida (1952) and the Cinematográfica Terras do Brasil: The presence of women in Brazilian cinema in the early 1950 s}

ABSTRACT The paper presents information about the initiative of Tânia Simões and Jovita de Almeida at the head of Cinematográfica Terras do Brasil, a production company founded in the early 1950s in São Paulo, which resulted in the shooting of a single feature film, Estrada da Vida (1952), classified as unfinished in the catalogue of Cinemateca Brasileira. Based on publications in the press and the film's original script, the article proposes a reflection on the exotified and distrustful approach to the presence of women in Brazilian cinema and poses questions about the filmmaking process and the whereabouts of its authors.

KEYWORDS Cinematográfica Terras do Brasil; Estrada da Vida (1952); Tânia Simões; Jovita de Almeida; women filmmakers.

Recebido a 16-07-2021. Aceite para publicação a 26-10-2021.

aniki A Pesquisa Histórica no Cinema Ibero-americano | Historical Research in Ibero-American Cinema 